\title{
Endometrial oxytocin receptor and uterine prostaglandin secretion in mares during the oestrous cycle and early pregnancy
}

\author{
G. R. Starbuck ${ }^{1}$, T. A. E. Stout ${ }^{2}$, G. E. Lamming ${ }^{1}$, W. R. Allen ${ }^{2}$ and \\ A. P. F. Flint ${ }^{1}$ \\ ${ }^{\mathrm{I}}$ Department of Physiology and Environmental Science, University of Nottingham, Sutton Bonington \\ Campus, Loughborough, Leicestershire LE12 5RD, UK; and ${ }^{2}$ Department of Clinical Veterinary Medicine \\ Equine Fertility Unit, University of Cambridge, Mertoun Paddocks, Newmarket, Suffolk CB8 9BH, UK
}

\begin{abstract}
Circulating concentrations of 13,14-dihydro-15-ketoprostaglandin $\mathrm{F}_{2 u}$ (PGFM) were measured before and after administration of oxytocin and after endometrial biopsy, with or without uterine flushing performed per vaginam, on days 10, 14 and 18 after ovulation in nine pregnant and nine cyclic mares. Concentrations of oxytocin receptor were measured in endometrial biopsy samples. Neither pregnancy status nor time after ovulation affected basal PGFM concentrations. PGFM concentrations were increased after oxytocin administration on each of the days studied in cyclic mares; on day 14 the mean response was 4.5 times higher than the mean response on days 10 and 18. In contrast, during pregnancy, responses to oxytocin administration occurred only on days 10 and 18. Marked increases in PGFM concentrations in response to endometrial biopsy occurred only on day 14 in cyclic mares and on day 18 in pregnant mares. Mean concentrations of oxytocin receptor were between 200 and $300 \mathrm{fmol} \mathrm{mg}^{-1}$ protein on day 10 in both pregnant and cyclic mares; in cyclic mares oxytocin receptor concentrations were increased approximately threefold on day 14 compared with days 10 and 1.8 , but no such increase was evident during pregnancy. Total amounts of PGFM secreted after oxytocin treatment correlated with endometrial oxytocin receptor concentrations in cyclic $(P<0.001)$ but not in pregnant $(P>0.5)$ mares, and the same was true for PGFM release induced by endometrial biopsy (cyclic: $P=0.0025$; pregnant: $P>0.5$ ). The data support the hypothesis that endometrial concentrations of oxytocin receptor determine uterine prostaglandin $\mathrm{F}_{2 u}$ secretion in cyclic mares and that endometrial oxytocin receptor concentrations are reduced in early pregnancy by a product of the conceptus. The increase in response of the pregnant uterus to oxytocin treatment or biopsy-flushing between days 14 and 18 was not due to an increase in the concentration of oxytocin receptors but presumably reflected increased receptor sensitivity.
\end{abstract}

\section{Introduction}

In mares, as in many other domestic animals, pulsatile uterine secretion of prostaglandin $\mathrm{F}_{2 \alpha}\left(\mathrm{PGF}_{2 u}\right)$ is thought to be responsible for cyclic luteolysis. Concentrations of $\mathrm{PGF}_{2 a}$ in the uterine vein are raised at the time of luteolysis (Douglas and Ginther, 1976), and circulating concentrations of the pulmonary metabolite of $\mathrm{PGF}_{2 \alpha^{\prime}}$ 13,14-dihydro-15-ketoPGF $2{ }_{2 \alpha}$ (PGFM) increase and decrease episodically at this time (Kindahl et al., 1982). Furthermore, the administration of $\mathrm{PGF}_{2 \alpha}$ or its analogues induces luteolysis in both dioestrus (Douglas and Ginther, 1972) and early pregnant (Kooistra and Ginther, 1976) mares. Although the mechanisms that lead to uterine $\mathrm{PGF}_{2 \alpha}$ secretion in mares are not well understood, in domestic ruminants, an initial release by the endometrium is induced by the action of oxytocin, probably of neurohypophyseal origin, on endometrial oxytocin receptors (McCracken et al., 1991;

Revised manuscript received 24 December 1997.
Silvia et al., 1991) the development of which is dependent on the steroid hormone environment (McCracken et al., 1984; Vallet et al., 1990). In turn, this $\mathrm{PGF}_{2 \alpha}$ stimulates the secretion of oxytocin from the corpus luteum (Flint and Sheldrick, 1982), creating a positive feedback loop that increases the magnitude of the $\mathrm{PGF}_{2 a}$ spike. There is evidence that oxytocin may also be involved in the luteolytic process in mares, since administration of exogenous oxytocin stimulates the release of $\mathrm{PGF}_{2 u}$ late in dioestrus (Betteridge et al., 1985; Goff et al., 1987, 1993), and circulating oxytocin concentrations are high at this time (Tetzke et al., 1987; but see Burns et al., 1981; Stevenson et al., 1991). Equine endometrium secretes $\mathrm{PGF}_{2 u}$ in response to oxytocin in vitro (King and Evans, 1984; Franklin et al., 1989) and expresses the oxytocin receptor (Stull and Evans, 1986).

Hershman and Douglas (1979) suggested that maternal recognition of pregnancy in mares occurs between days 14 and 16 after ovulation since removal of the conceptus from the uterus during this period results in prolonged luteal function. However, Betteridge et al. (1985) noted that the procedure of 
flushing the blastocyst from the uterus could itself extend the luteal phase. Subsequently, Goff et al. (1987) suggested that maternal recognition of pregnancy in mares may occur between days 11 and 13 because the PGFM response to oxytocin challenge of cyclic mares increased markedly during this period, while administration of oxytocin to pregnant mares between days 9 and 14 after ovulation did not change plasma PGFM concentrations. Furthermore, $\mathrm{PGF}_{2 u}$ concentrations in uterine venous plasma (Douglas and Ginther, 1976), peripheral plasma (Kindahl ef al., 1982) and the uterine lumen (Zavy et al., 1984) are reduced in pregnant compared with cyclic animals at equivalent stages after ovulation. Therefore, it appears likely that the prevention of luteal regression during early pregnancy results from inhibition of the mechanisms that lead to uterine $\mathrm{PGF}_{2 u}$ secretion. The conceptus signal exerting this effect has not been identified.

There is considerable uncertainty surrounding the mechanism and the timing of maternal recognition of pregnancy in the mare, and a lack of information on any correlation between the ability of the uterus to respond to oxytocin and oxytocin receptor concentrations. The aim of this study was to investigate the temporal changes in these two parameters of uterine responsiveness to oxytocin in cyclic and early pregnant mares at comparable stages after ovulation.

\section{Materials and Methods}

\section{Animals}

The experimental animals included ten Welsh pony mares and eight thoroughbred mares between 3 and 15 years of age and weighing 229-514 and 518-640 kg, respectively. These animals had all previously exhibited normal cyclicity and were of proven fertility. In addition, five of the mares had foals at foot; since all foals were $>4$ months old, their frequency of suckling was low. The mares and foals were housed together and only when the mares were restrained in stocks for biopsy or uterine lavage was suckling prevented. During periods of treatment and serial bleeding, all mares were housed in separate looseboxes where they had free access to hay and water.

The time of ovulation was determined by daily measurements of blood serum progesterone (AELIA assay; Dako Diagnostics, Cambridge) in conjunction with transrectal realtime ultrasonography of the ovaries using a $5 \mathrm{MHz}$ transducer (Concept 2000; Dynamic Imaging, Livingstone). The day of ovulation in pony mares was taken as the day before serum progesterone concentrations rose to $>1 \mathrm{ng} \mathrm{ml}^{-1}$; in the thoroughbred mares, because the postovulatory increase in progesterone often takes $>24 \mathrm{~h}$, the day of ovulation was taken as the day on which the dominant follicle disappeared and was replaced by a corpus haemorrhagicum.

Pony and thoroughbred mares in the pregnant groups were inseminated on alternate days during oestrus with $>500 \times 10^{6}$ progressively motile stallion spermatozoa extended $2: 1(\mathrm{v} / \mathrm{v})$ with a skimmed milk-glucose diluent. Pregnancy was determined by transrectal ultrasonography on day 10 after ovulation and three mares were allotted at random to each of the day 10, 14 and 18 pregnant groups. Nine mares were not inseminated and three were allotted to each of the day 10, 14 and 18 of cycle groups. The mares were assigned to experimental groups at random. The five mares with foals at foot were assigned randomly to the various treatment groups.

\section{Bleeding schedules}

Samples of blood $(7 \mathrm{ml})$ were collected via indwelling jugular cannulae inserted through a subcutaneous bleb of lignocaine hydrochloride (Lignocaine A; Univet, Bicester) at least $1 \mathrm{~h}$ before the start of the experiment. Catheter patency was maintained by flushing with $1 \mathrm{ml}$ heparinized saline (10 000 iu heparin $\mathrm{ml}^{-1}$ ) after removal of each sample. Oxytocin was administered through the same jugular cannula at a dose of 20 iu per $500 \mathrm{~kg}$ body weight. Blood samples were allowed to clot for $30 \mathrm{~min}$ before being centrifuged at $1500 \mathrm{~g}$ for $10 \mathrm{~min}$, and serum was decanted and stored at $-20^{\circ} \mathrm{C}$ until assay. Samples were taken at $15 \mathrm{~min}$ intervals for an initial $5 \mathrm{~h}$ period and at $10 \mathrm{~min}$ intervals thereafter. Oxytocin was administered immediately after the sixth hourly bleed, and this was followed by a further $\mathrm{I} h$ of sampling at $10 \mathrm{~min}$ intervals. This frequency of sample collection was necessary to avoid overlooking surges of $\mathrm{PGF}_{2 u^{\prime}}$ as described by Granstrom and Kindahl (1976).

\section{Endometrial biopsy}

Endometrial biopsies were collected using sterile uterine biopsy forceps guided through the cervix and into the uterus. Samples of endometrium (approximately $0.5 \mathrm{~g}$ ) obtained in this way were wrapped in aluminium foil, snap-frozen in liquid nitrogen and stored at $-196^{\circ} \mathrm{C}$ for oxytocin receptor assay. In pregnant mares, embryos were flushed from the uterus immediately before biopsy collection by large volume uterine lavage, using PBS passed via a sterile flexible polyvinyl chloride catheter $(130 \mathrm{~cm}$ length, $19 \mathrm{~mm}$ internal diameter) manually guided through the cervix, to prevent possible contamination of biopsy samples with conceptus tissue.

\section{3,14-Dihydro-15-ketoPGF ${ }_{2 a}$ radioimmunoassay}

Concentrations of PGFM in $0.5 \mathrm{ml}$ aliquots of serum were measured using a specific solvent extracted radioimmunoassay adapted from that described by Kaker et al. (1984). Blank horse serum spiked with PGFM at concentrations of 80 and $190 \mathrm{pg}$ $\mathrm{ml}^{-1}$ showed mean recoveries of $87.8 \%$ and $80.0 \%$, respectively. The PGFM antiserum was raised in rabbits by F. W. Bazer, Texas A\&M University, TX, and crossreacted < $1 \%$ with arachidonic acid, $\mathrm{PGE}_{2}, \mathrm{PGF}_{1 \alpha}$ or $\mathrm{PGF}_{2 \alpha}$. The limit of sensitivity of the assay was $13.2 \mathrm{pg} \mathrm{ml}^{-1}$ and the intra-assay and interassay coefficients of variation were $3.3 \%$ and $13.3 \%$, respectively.

\section{Oxytocin receptor assay}

The sheep oxytocin receptor assay of Sheldrick and Flint (1985) was modified and validated for use in the horse (E. J. Benfield, personal communication). Subcellular fractions of endometrial biopsy were prepared and suspended in $2 \mathrm{ml}$ 
Tris- $\mathrm{HCl}\left(25 \mathrm{mmol} 1^{-1} ; \mathrm{pH} \mathrm{7.6}\right)$ and stored at $-196^{\circ} \mathrm{C}$ until assayed. Protein concentrations in the preparations were determined using a bicinchoninic acid protein assay kit (Pierce and Warriner Ltd, Chester; Smith et al., 1985), using BSA standards. Optimization was carried out using endometrial subcellular fractions prepared from a uterus recovered post mortem from a horse on the day of ovulation (day 0$).\left[{ }^{3} \mathrm{H}\right] \mathrm{O} x y$ tocin binding was optimized for incubation temperature, time and cation concentration. In the sheep oxytocin receptor assay $\mathrm{Mn}^{2+}$ is added in the form of $\mathrm{MnCl}_{2}$ and, in the cow assay (Jenner et al., 1991) $\mathrm{Mg}^{2+}$ is added as $\mathrm{MgCl}_{2}$ to enhance receptor binding. When the effects of these two ions on receptor binding in equine tissue extracts were investigated at concentrations of 0 , $1,5,10$ and $20 \mathrm{mmol}^{-1}$, binding increased from 0 to $10 \mathrm{mmol} \mathrm{\textrm {I } ^ { - 1 }}$ but not when concentrations were increased further. $\mathrm{MnCl}_{2}$ increased binding to a greater extent than $\mathrm{MgCl}_{2}(P=0.05)$ and, therefore, $10 \mathrm{mmol} \mathrm{MnCl}_{2} 1^{-1}$ was used to give optimal binding. Oxytocin binding was proportional to the concentration of protein added to the assay tube and Scatchard plots were linear $\left(K_{\mathrm{d}}\right.$ approximately $\left.1.2 \mathrm{nmol}^{-1}\right)$.

After optimization, the assay procedure was as follows. Receptor fractions ( $50 \mu \mathrm{g}$ protein) were incubated in triplicate at $30^{\circ} \mathrm{C}$ for $30 \mathrm{~min}$ in $0.1 \mathrm{ml}$ Tris- $\mathrm{HCl}\left(25 \mathrm{mmol}^{-1} ; \mathrm{pH} \mathrm{7.6)}\right.$ containing $0.1 \%(\mathrm{w} / \mathrm{v}) \mathrm{BSA}$ (buffer $\mathrm{A}$ ), $10 \mathrm{mmol} \mathrm{MnCl} \mathrm{L}^{-1}$ and $\left[{ }^{3} \mathrm{H}\right]$ oxytocin $\left(20 \mathrm{nmol} \mathrm{l}^{-1}, 36.6\right.$ or $48.5 \mathrm{Ci} \mathrm{mmol} \mathrm{l}^{-1}$; NEN, Dupont (UK) Ltd, Stevenage). Nonspecific binding was measured in the presence of $80 \mathrm{pmol}$ unlabelled oxytocin. After incubation, assay tubes were transferred to an ice bath $\left(0.5^{\circ} \mathrm{C}\right)$ and $2 \mathrm{ml}$ ice-cold buffer $\mathrm{A}$ was added. The suspended receptor protein was removed from incubation media by filtration under vacuum (Whatman GF/F filters, pore size $0.7 \mu \mathrm{m}$; Whatman International Ltd, Maidstone) and washed twice with $2 \mathrm{ml}$ buffer $A$. The filters were transferred to scintillation vials containing $8 \mathrm{ml}$ scintillation fluid (Ultima Gold, Packard Canberra, Pangbourne) and counted using a Packard 1900CA TRI-CARB counter (Packard Canberra). Nonspecific binding was measured in triplicate in the presence of unlabelled oxytocin and the results are expressed as $\mathrm{fmol} \mathrm{mg}^{-1}$ protein.

\section{Progesterone assay}

Serum progesterone concentrations were measured using an amplified enzyme-linked immunoassay (AELIA) kit (Dako Diagnostics) described for use in horses by Allen and Sanderson (1987). A monoclonal anti-progesterone antibody raised in mice was used in the assay and it was bound to the surface of wells in a microtitre plate. Standard or sample serum $(20 \mu \mathrm{l})$ was added to each well followed by $100 \mu \mathrm{l}$ progesterone-alkaline phosphatase conjugate. Reaction solutions were discarded and each well was washed three times with $250 \mu \mathrm{l}$ assay buffer $(2 \%(\mathrm{w} / \mathrm{v})$ sodium azide in doubledistilled water). Nicotinamide adenine dinucleotide phosphate $\left(0.1 \mathrm{ml}\right.$ of $0.2 \mathrm{nmol} \mathrm{l}^{-1}$ solution in $0.9 \mathrm{~mol}$ diethanolamine $~^{-1}$ ) was then added to each well and, after $10 \mathrm{~min}, 100 \mu \mathrm{l}$ of enzyme amplifier solution (containing alcohol dehydrogenase, lipoamide dehydrogenase, ethanol and iodonitrotetrazolium violet in phosphate buffer) was added. Colour development was stopped after $7 \mathrm{~min}$ by the addition of $0.2 \mathrm{~mol}$ sulphuric acid $l^{-1}$. Absorbance was measured at $492 \mathrm{~nm}$ using a plate scanning spectrophotometer and the results are expressed in ng $\mathrm{ml}^{-1}$. The sensitivity of the assay was $0.135 \mathrm{ng} \mathrm{ml}^{-1}$ and the intra- and interassay coefficients of variation were $6 \%$ and $8 \%$, respectively (Allen and Sanderson, 1987). For progesterone antibody crossreactivity data, see Stanley et al. (1986).

\section{Statistical analysis}

Mean baseline PGFM concentrations were calculated from pretreatment data for each animal. In calculating mean baseline serum PGFM concentrations, any points forming a peak of two or more points above the mean plus $2 \mathrm{SD}$ during the pretreatment period were assumed to represent spontaneous episodes of release and were omitted from the calculation. The effects of day and pregnancy state on the mean baseline PGFM concentration were determined by two-way ANOVA.

An oxytocin-induced PGFM response was defined as a point or series of points above the pretreatment mean plus $2 \mathrm{sD}$, immediately after oxytocin administration, lasting until this response declined below this concentration, or until the uterus of the animal was flushed or an endometrial biopsy was taken. The peak height (highest point during the response), response duration and amount of PGFM released in the peak were determined for each response; data are presented only for the amount of PGFM released, calculated as the total area under the response curve above mean base line concentration, since this parameter is a product of peak height and duration. The effect of pregnancy status and day on the peak height and amount of PGFM released were determined by two-way ANOVA. The data for amount of PGFM released were squareroot transformed to eliminate heterogeneity of variance. Where there was a significant interaction, multiple comparisons were made using the Student-Newman-Keuls test.

The effect of pregnancy state and day after ovulation on uterine endometrial oxytocin receptor concentration and progesterone concentration in blood serum was tested using two-way ANOVA. Multiple comparisons of the data were then made using the Student-Newman-Keuls test.

Mean serum concentrations of progesterone were high in all cyclic mares on days 10 and 14 (Fig. 1) and decreased when luteolysis occurred between days 14 and 18. In pregnant animals, the mean concentrations remained high on day 18 .

The mean circulating serum concentration of PGFM during the pretreatment period was $32 \pm 1.8 \mathrm{pg} \mathrm{ml}^{-1}(n=18)$ and there was no significant difference in baseline PGFM concentration with regard to day or pregnancy state. Large pretreatment episodes of $\mathrm{PGF}_{2 \alpha}$ release, reflected in increased PGFM concentrations, were detected in two cyclic mares on day 14 after ovulation but in none of the three cyclic mares sampled on day 18 . There was also a small episode of $\mathrm{PGF}_{2 \alpha}$ release in one day 10 cyclic mare. One day 18 pregnant mare showed two small episodes of $\mathrm{PGF}_{2 \alpha}$ secretion, but no other episodes were detected in any of the pregnant animals sampled.

Mean PGFM responses to oxytocin and to uterine biopsy and uterine flushing are shown (Figs 2 and 3). On each of the days studied, all cyclic mares showed a response to oxytocin, 


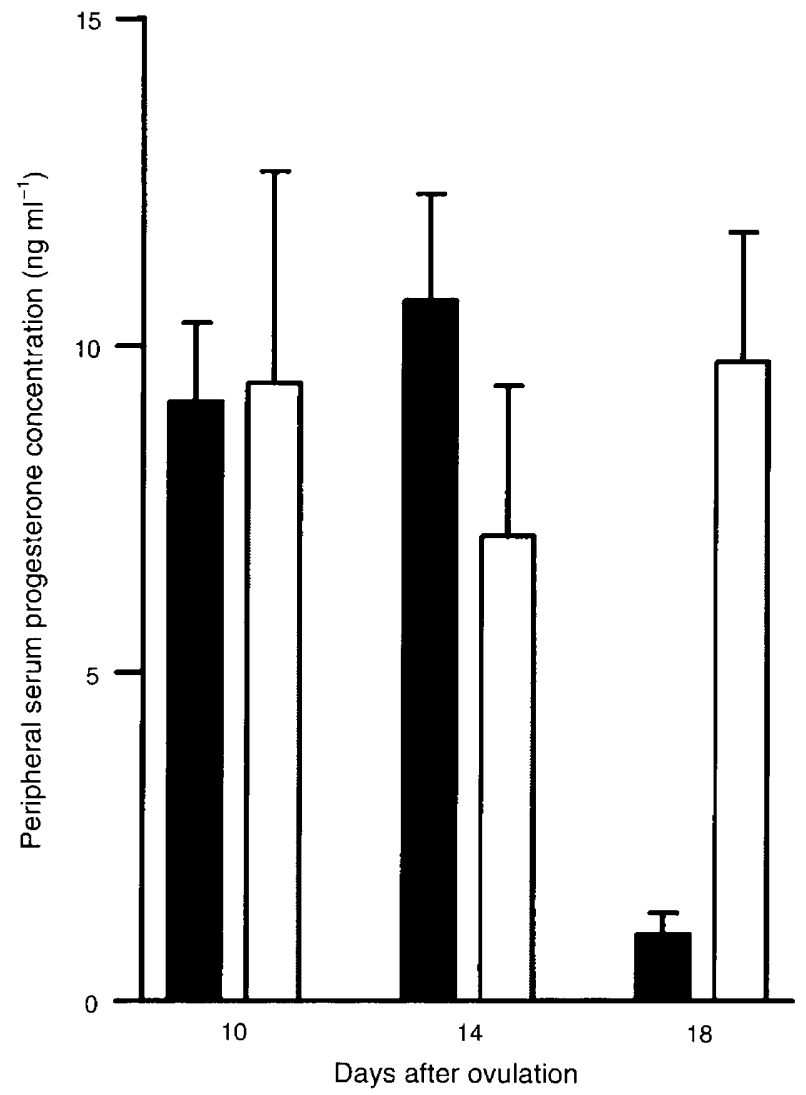

Fig. 1. Peripheral serum progesterone concentration in pregnant $(\square)$ and nonpregnant ( $\boldsymbol{\square}$ ) mares on days 10,14 and 18 after ovulation. Results are expressed as mean values $\pm \mathrm{SEM}, n=3$ for each group.

which only failed to reach statistical significance in one day 10 mare. The magnitude of this response was greatest on day 14 after ovulation (mean 4.5 times higher than the mean for days 10 and 18). In pregnant mares, a low response to oxytocin occurred in two of the three animals on day 18 (mean response on day 18 was 3.4 times higher than that on days 10 and 14). Significant PGFM responses to biopsy were observed only in day 14 cyclic mares and to uterine flushing and biopsy only in day 18 pregnant mares.

Mean oxytocin receptor concentrations (Fig. 4) were significantly affected by pregnancy status, day after ovulation and a combination of the two $(P=0.021)$. In cyclic animals, mean oxytocin receptor concentrations were increased 3.3 times on day 14 after ovulation compared with concentrations on days 10 and $18(P<0.05)$. In contrast, oxytocin receptor concentrations were unchanged during the same period of pregnancy. There was no difference in receptor concentration between pregnant and cyclic mares on days 10 or 18 , but receptor concentrations were higher $(P<0.05)$ in cyclic mares than in pregnant mares on day 14. The PGFM response to oxytocin challenge in cyclic mares was highly correlated with endometrial oxytocin receptor concentrations $(r=0.9143, P<0.001$; Fig. 5a), but this relationship was absent in pregnancy (Fig. 5a; $r=0.2121, P>0.5$ ). Although there was a marked difference with respect to day after ovulation in the PGFM response to manipulation of the pregnant uterus (Fig. 5b), with a maximum response in day 18 pregnant mares, this increased response

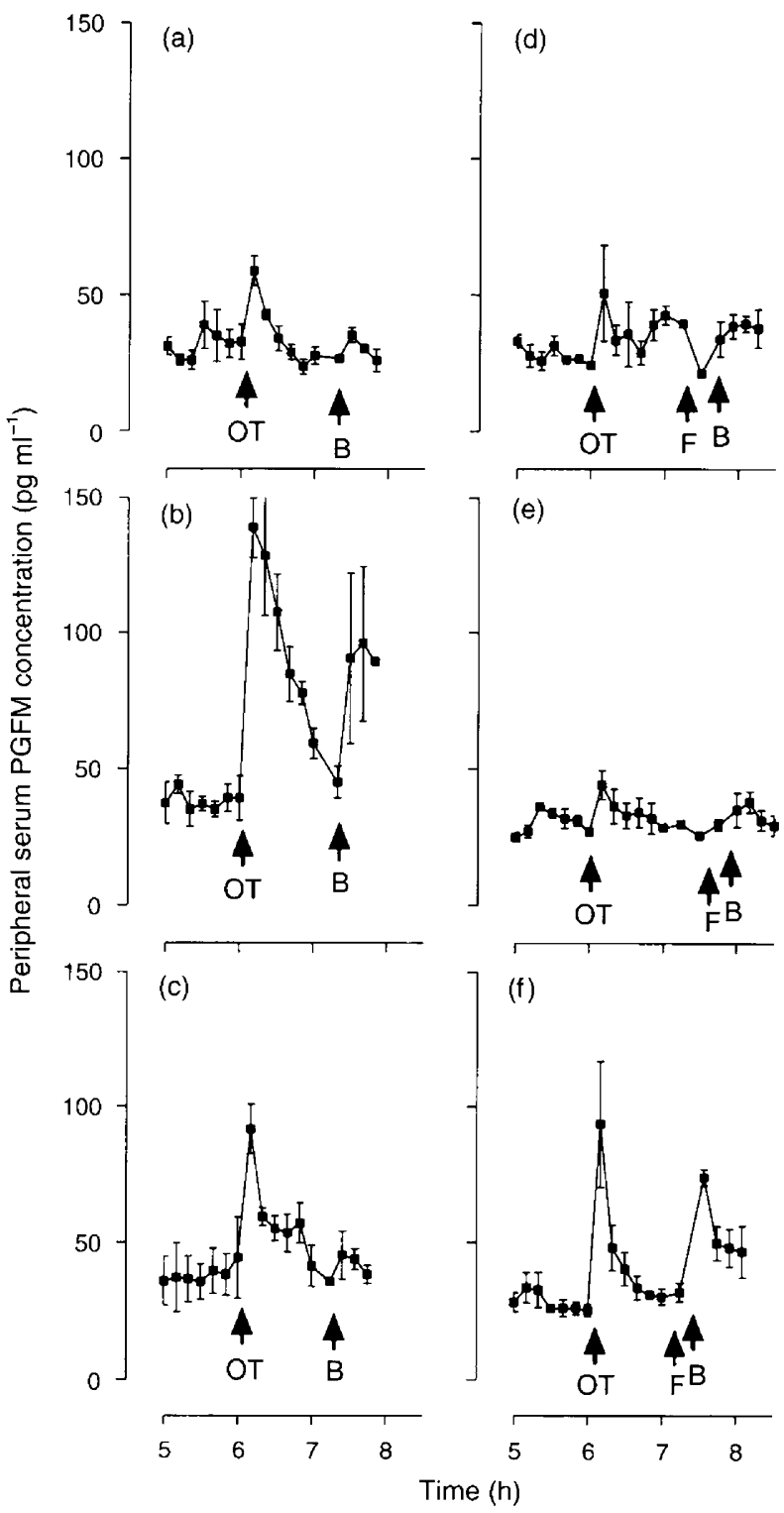

Fig. 2. Peripheral serum 13,14-dihydro-15-ketoprostaglandin $F_{2 u}$ (PGFM) concentrations before and after administration of oxytocin (OT) or endometrial biopsy (B), with or without flushing the conceptus from the uterus $(F)$ in nonpregnant $(a-c)$ and pregnant $(d-f)$ mares on days $10(\mathrm{a}, \mathrm{d}), 14(\mathrm{~b}, \mathrm{e})$ and $18(\mathrm{c}, \mathrm{f})$ after ovulation. Values are means \pm SEM, $n=3$ for each group.

later in pregnancy was independent of any increase in endometrial oxytocin receptor concentration (response in nonpregnant animals: $r=0.8667, P<0.005$; in pregnancy: $r=0.1175$, $P>0.05$ ).

\section{Discussion}

The detection of spontaneous episodes of $\mathrm{PGF}_{2 \alpha}$ release on day 14 in nonpregnant mares is consistent with uterine secretion of the luteolytic agent at this time and the decrease in circulating concentrations of progesterone between days 14 and 18 demonstrated the normal occurrence of luteolysis. The present 


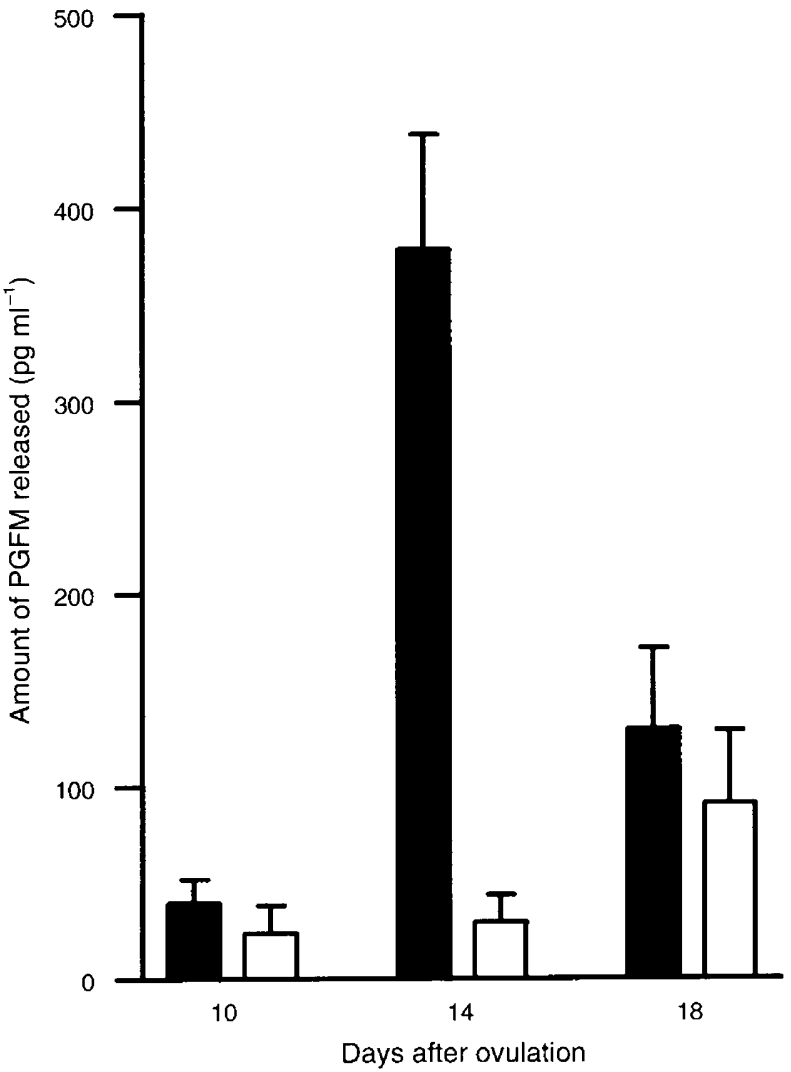

Fig. 3. 13,14-Dihydro-15-ketoprostaglandin $F_{2 u}$ (PGFM) release after oxytocin administration in pregnant $(\square)$ and nonpregnant $(\boldsymbol{\square})$ mares on days 10,14 and 18 after ovulation. Values are quantities of PGFM appearing in serum after treatment calculated from the area under curves of concentration versus time. Values are means \pm SEM, $n=3$ for each group.

study also revealed that the marked increase in $\mathrm{PGF}_{2, \alpha}$ secretion in response to oxytocin administration on day 14 in cyclic mares was correlated with an increase in endometrial oxytocin receptor concentrations at this time: uterine response was proportional to receptor concentration. This finding illustrates an increase in the sensitivity of the uterus to oxytocin at the appropriate time in the oestrous cycle which is consistent with the suggestion that oxytocin is responsible for stimulating the episodic release of $\mathrm{PGF}_{2 a}$ from the endometrium during luteolysis. The present data do not indicate at which stage after oestrus maximum oxytocin receptor concentrations or $\mathrm{PGF}_{2 \alpha}$ release responses occurred; it may be that peak PGFM and oxytocin receptor concentrations were higher during days 11-13 or days 15-17 than on day 14. The data also support the proposal of Goff et al. (1987) that if maternal recognition of pregnancy in the mare is mediated by prevention of the increased uterine response to oxytocin and, as shown in the present study, the increased endometrial oxytocin receptor concentration, then this process must be complete before day 14 after ovulation.

If oxytocin is the stimulus for $\mathrm{PGF}_{2 a}$ release during luteolysis in mares then, in contrast to the situation in ruminants (Flint and Sheldrick, 1982; Wathes and Swann, 1982), it is unlikely to be secreted by the corpus luteum. Stevenson $e$ al. (1991) were unable to detect significant amounts of oxytocin in equine

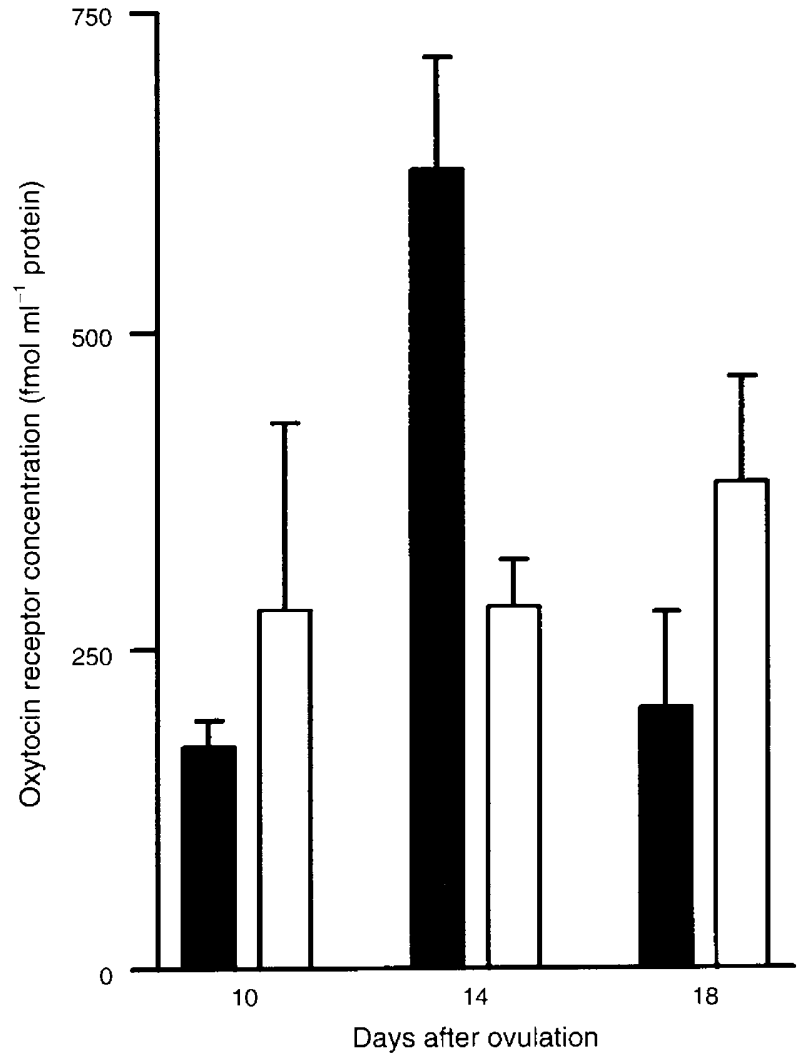

Fig. 4. Endometrial oxytocin receptor concentrations in pregnant ( $\square$ ) and nonpregnant $(\mathbf{D})$ mares on days 10,14 and 18 after ovulation. Values are means \pm SEM, $n=3$ for each group.

Iuteal tissue at any stage of the oestrous cycle, and oxytocin was not detected in ovarian venous blood recovered from a mare undergoing luteolysis (A. P. F. Flint and W. R. Allen, unpublished). Oxytocin secretion from the posterior pituitary gland during the oestrous cycle, as revealed by intercavernous sinus sampling, shows that this is the most likely source (Vanderwall et al., 1998).

Although it is possible that suckling and milk ejection involve neurohypophyseal oxytocin release provoking an endometrial $\mathrm{PGF}_{2 u}$ response in mares with foals at foot, Vivrette (1995) concluded that suckling is not significantly correlated with oxytocin release in mares. Release of oxytocin into the intercavernous sinus cannulated by the method of Irvine and Alexander (1987) was associated with suckling in only one of five lactating mares and, after a period of separation, there was no oxytocin release after the resumption of suckling by the foal. This result strengthened the previous findings that, on the basis of the measurement of oxytocin in jugular venous blood, oxytocin is not essential to milk let down in mares (Ellendorff and Schamms, 1988).

In pregnant mares, uterine sensitivity to oxytocin was independent of oxytocin receptor concentration. This difference between cyclic and pregnant animals may be explained by a product of the conceptus exerting two effects: (1) decreasing oxytocin receptor concentrations on day 14 , relative to the cyclic state, and (2) interfering with coupling of the receptor to second messenger systems responsible for $\mathrm{PGF}_{2 \alpha}$ synthesis and secretion until day 18 . Restored coupling between day 14 


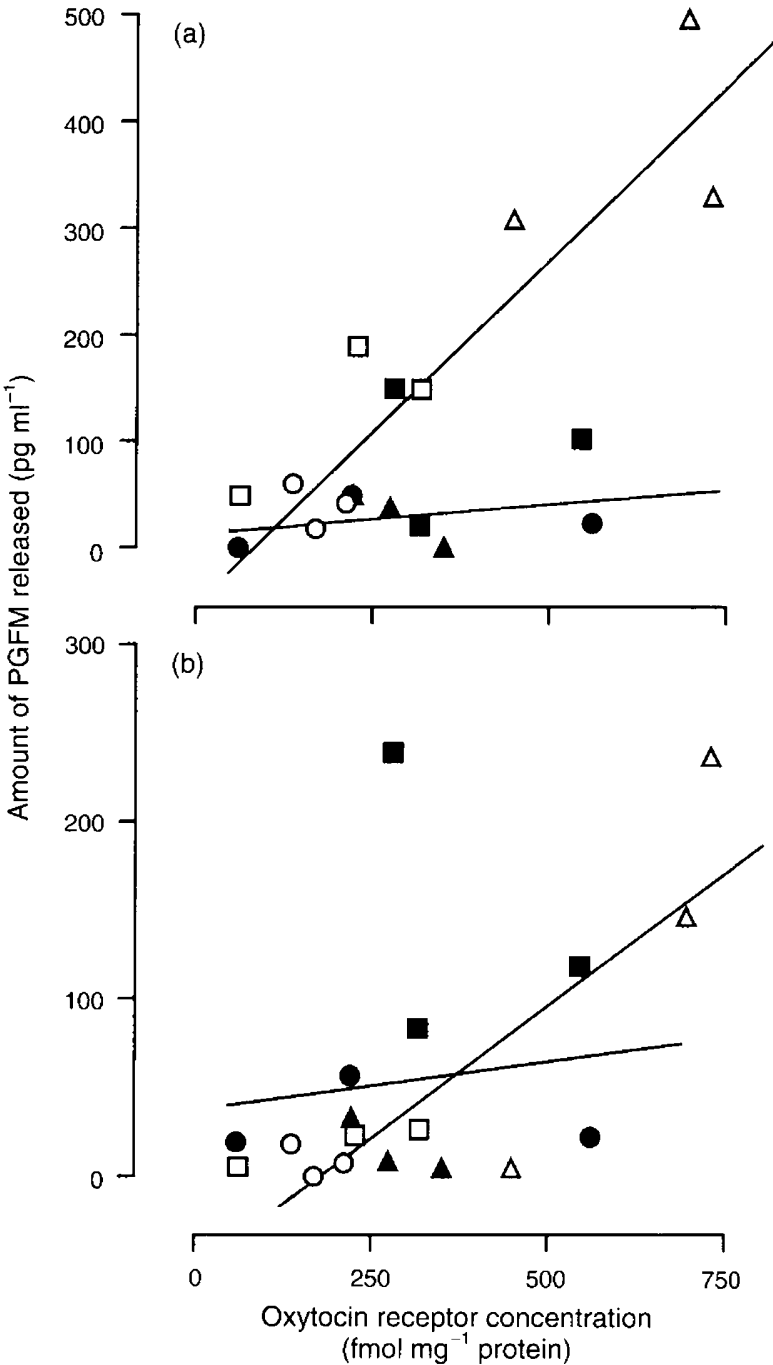

Fig. 5. Correlations between 13,14-dihydro-15-ketoprostaglandin $\mathrm{F}_{2 u}$ (PGFM) release and endometrial oxytocin receptor concentrations in pregnant $(\boldsymbol{\square}, \mathbf{\Delta}, \boldsymbol{O})$ and nonpregnant $(\square, \triangle, \bigcirc)$ mares on days 10 $(\boldsymbol{\bullet}, \bigcirc), 14(\boldsymbol{\Delta}, \triangle)$ and $18(\boldsymbol{\square}, \square)$ after ovulation. (a) Responses to exogenous oxytocin administration (in nonpregnant animals: $r=0.9143, \quad p<0.001$; in pregnancy; $r=0.2121, \quad p>0.5)$. (b) Responses to biopsy with or without embryo flushing manipulation (in nonpregnant animals: $r=0.8667, P<0.005$; in pregnancy: $r=0.1175, P>0.05)$. Regression lines are fitted by linear regression for pregnant and nonpregnant values separately.

and day 18 could account for the increased response observed on day 18.

PGFM responses to the cervical manipulation and uterine distension caused by biopsy and flushing were correlated with oxytocin receptor concentrations in cyclic mares but, as with the response to oxytocin administration, this correlation was not present in pregnant mares. This again suggests that changes in $\mathrm{PGF}_{2 \alpha}$ release in response to biopsy and flushing during early pregnancy involved mechanisms that altered oxytocin receptor function rather than concentration. However, since pregnant animals were flushed, while cyclic animals were not, it is not possible to conclude that the reduced oxytocin receptor concentrations and reduced PGFM responses to biopsy seen in pregnancy were a consequence of pregnancy, rather than of flushing. It was necessary to flush the conceptuses from the pregnant mares before biopsy to avoid contamination of endometrium with conceptus tissue. Of the parameters measured (PGFM response to oxytocin, PGFM response to biopsy and the oxytocin receptor concentration), only the PGFM response to biopsy could have been affected by flushing. The PGFM response to oxytocin was measured before flushing. The amount of oxytocin receptor is unlikely to have been affected, as the receptor is a seven transmembrane molecule that is structurally integrated into the cell membrane, and would not be expected to be lost without gross structural damage, for which there is no evidence after flushing. The receptor can only be removed from cell membranes in vitro with highly acidic solutions. Furthermore, the range of receptor concentrations observed was similar in cyclic and pregnant mares, although only those that were pregnant were flushed. Flushing is unlikely to have caused PGFM secretion, since there was none on days 10 and 14 in pregnant mares, and the release seen on day 18 occurred after biopsy, not before it. That biopsy can cause PGFM release is shown by the response of day 14 cyclic mares. Therefore, there is no evidence to suggest that the response to biopsy on day 18 of pregnancy is in fact a response to flushing the uterus.

One observation arising from the present study that may have clinical implications concerns the way in which pregnant mares become responsive to oxytocin administration and uterine manipulation around day 18 after ovulation. Uterine manipulation, such as that performed during pregnancy diagnosis or manual per rectum twin reduction, could potentially cause a luteolytic $\mathrm{PGF}_{2 u}$ episode and thus induce embryonic loss. The increased sensitivity of the uterus to oxytocin on day 18 of pregnancy also raises the question, why does luteolysis not occur at this time? The response to oxytocin on day 18 was lower than that in day 14 cyclic mares and, if oxytocin secretion were to occur on day 18 of pregnancy, $\mathrm{PGF}_{2 u}$ secretion may be too low or infrequent to cause luteolysis.

The unusually high incidence of spontaneous prolongation of luteal function, occurring in approximately $20 \%$ of mares at least once during each breeding season (Stabenfeldt $e t$ al., 1974, 1981; King and Evans, 1984), and the high early embryonic loss to which horses appear to be prone, are major causes of infertility, time loss and, therefore, economic loss in horse breeding. Indeed, Woods et al. (1987) suggested that $13 \%$ of conceptuses are lost in early pregnancy, with the rate of loss being highest between days 14 and 28 , when $35 \%$ of the total loss occurred. A proportion of these early pregnancy failures probably results from an abnormal pairing of chromosomes at the time of fertilization (Allen, 1992). Further loss may result from failure of the developing conceptus adequately to prevent $\mathrm{PGF}_{2 \alpha}$ release and, therefore, prevent luteolysis. The present data demonstrate the subtlety of the changes in uterine sensitivity to oxytocin occurring at this critical time.

The authors thank the staff of the Equine Fertility Unit, University of Cambridge for assistance with animal management, and E. Benfield, M. Hunter, D. Scholey and G. Mann for help with assays, provision of unpublished data and useful advice. We are grateful to F. W. Bazer for gifts of PGFM antiserum. 


\section{References}

Allen WR (1992) The diagnosis and handling of early gestational abnormalities in the mare Animal Reproduction Science 28 31-38

Allen WR and Sanderson MW (1987) The value of a rapid progesterone assay (AELIA) in equine stud veterinary medicine and management Proceedings of the 9th Bain-Fallen Memorial Lectures: the mare and foal

Betteridge KJ, Renard A and Goff AK (1985) Uterine prostaglandin release relative to embryo collection, transfer procedures and maintenance of corpus luteum Equine Veterinary Journal Supplement 3 25-33

Burns PJ, Kumaresan P and Douglas RH (1981) Plasma oxytocin concentrations in cyclic mares and sexually aroused stallions Theriogenology 16 531-539

Douglas RH and Ginther OJ (1972) Effect of prostaglandin $F_{2 u}$ on length of dioestrus in mares Prostaglandins 2 265-268

Douglas RH and Ginther OJ (1976) Concentration of prostaglandin F in uterine venous plasma of anaesthetised mares during the estrous cycle and early pregnancy Prostaglandins 11 251-260

Ellendorff F and Schams D (1988) Characteristics of milk ejection, associated intra-mammary pressure changes and oxytocin release in the mare journal of Endocrinology 119 219-227

Flint APF and Sheldrick (1982) Ovarian secretion of oxytocin is stimulated by prostaglandin Nature 297 587-588

Franklin KS, Gross TS, Dubois DH and Sharp DC (1989) In vitro prostaglandin secretion from luminal and myometrial sides of endometrium from cyclic and pregnant mares at day 14 post-estrus Biology of Reproduction Supplement 140 114

Goff AK, Pontbriand D and Sirois J (1987) Oxytocin stimulation of plasma 15-keto-13,14-dihydro prostaglandin $\mathrm{F}_{2 u}$ during the oestrous cycle and early pregnancy in the mare Journal of Reproduction and Fertility Supplement 35 253-260

Goff AK, Sirois J and Pontbriand D (1993) Effect of oestradiol on oxytocin stimulated prostaglandin $\mathrm{F}_{2 a}$ release in mares Journal of Reproduction and Fertility 98 107-112

Granstrom E and Kindahl H (1976) Radioimmunoassay for prostaglandin metabolites. In Advances in Prostaglandin and Thromboxane Research 1 pp 81-92 Eds B Samuelsson and R Paoletti. Raven Press, New York

Hershman L and Douglas RH (1979) The critical period for the maternal recognition of pregnancy in pony mares Journal of Reproduction and Fertility Supplement 27 395-401

Irvine CHG and Alexander SL (1987) A novel technique for measuring hypothalamic and pituitary hormone secretion rates from collection of pituitary venous effluent in the normal horse Journal of Endocrinology 113 183-192

Jenner LJ, Parkinson TJ and Lamming GE (1991) Uterine oxytocin receptors in cyclic and pregnant cows Journal of Reproduction and Fertility 91 49-58

Kaker ML, Murray RD and Dobson H (1984) Plasma hormone changes in cows during induced or spontaneous calvings and the early post-partum period Veterinary Record 115 378-382

Kindahl H, Knudsen O, Medej A and Edqvist LE (1982) Progesterone prostaglandin $\mathrm{F}_{2 u^{\prime}}$ PMSG and oestrone sulphate during early pregnancy in the mare Journal of Reproduction and Fertility Supplement 32 353-359

King SS and Evans JW (1984) Equine endometrial PGF $_{2 u}$ production in response to oxytocin and arachidonic acid during the estrus cycle and spontaneously prolonged corpus luteum syndrome Proceedings of the 10th International
Congress on Animal Reproduction and Artificial Insemination Urbana-Champaign 1483

Kooistra LH and Ginther OJ (1976) Termination of pseudopregnancy by administration of prostaglandin $\mathrm{F}_{2 u}$ or colchicine or by removal of embryo in mares American Journal of Veterinary Research 37 35-39

McCracken JA, Schamm W and Okulicz WC (1984) Hormone receptor control of pulsatile secretion of $\mathrm{PGF}_{2: x}$ from the ovine uterus during luteolysis and its abrogation in early pregnancy Animal Reproduction Science 7 31-55

McCracken JA, Smith TT, Lamsa JC and Robinson AG (1991) The effect of estradiol-17ß (E) and progesterone (P) on oxytocin (OT) pulse generator in the ovexed sheep Biology of Reproduction 44 Supplement 1, Abstract 137

Sheldrick EL and Flint APF (1985) Endocrine control of uterine oxytocin receptors in the ewe Journal of Endocrinology 106 249-260

Silvia WJ, Lewis GS, McCracken JA, Thatcher WW and Wilson JR (1991) Hormonal regulation of uterine secretion of prostaglandin $F_{2 u}$ during luteolysis in ruminants Biology of Reproduction 45 655-663

Smith PK, Krohn RI, Hermanson GT, Mallia AK, Gartner FH, Provenzano MD, Fujimoto EK, Goeke NM, Olson BJ and Klenk DC (1985) Measurement of protein using bicinchoninic acid Analytical Biochemistry 150 76-85

Stabenfeldt GH, Hughes JP, Evans JW and Neely DP (1974) Spontaneous prolongation of luteal activity in the mare Acta Veterinaria Scandinavica Supplement $\mathbf{7 7}$ 159-170

Stabenfeldt GH, Kindahl H, Hughes JP, Neely DP, Liu I and Pascoe D (1981) Control of luteolysis in the mare Equine Veterinary Journal 6 158-163

Stanley CJ, Paris F, Webb AE, Heap RB, Ellis ST, Hamon M, Worsefold A and Booth JM (1986) Use of a new rapid milk progesterone assay to monitor reproductive activity in the cow Veterinary Record 118 664-667

Stevenson KR, Parkinson TJ and Wathes DC (1991) Measurement of oxytocin concentrations in plasma and ovarian extracts during the oestrous cycle of mares Journal of Reproduction and Fertility 93 437-441

Stull CL and Evans JW (1986) Oxytocin binding in the uterus of the cycling mare Journal of Equine Veterinary Science 6 114-119

Tetzke TA, Ismail S, Mikuckis G and Evans JW (1987) Patterns of oxytocin secretion during the oestrous cycle of the mare Journal of Reproduction and Fertility Supplement 35 245-252

Vallet JL, Lamming GE and Batten M (1990) Control of endometrial oxytocin receptor and uterine response to oxytocin by progesterone and oestradiol in the ewe Journal of Reproduction and Fertility $90625-634$

Vanderwall DK, Silvia WJ and Fitzgerald BP (1998) Concentrations of oxytocin in the intercavernous sinus of mares during luteolysis: temporal relationship with concentrations of 13,14-dihydro-15-ketoprostaglandin $F_{2 u}$ journal of Reproduction and Fertility 112 337-346

Vivrette S (1995) Oxytocin secretion patterns in the intercavenous sinus of the mare around the time of foaling Proceedings of the PD Rossdale International Workshop on Equine Perinatology Abstract booklet $\mathrm{p} 15$

Wathes DC and Swann RW (1982) Is oxytocin an ovarian hormone? Nature 297 225-227

Woods GL, Baker CB, Baldwin JL, Ball BA, Bilinski J, Cooper WL, Ley WB, Monk EC and Erb HN (1987) Early pregnancy loss in brood mares Journal of Reproduction and Fertility Supplement 35 455-459

Zavy MT, Vernon MW, Asquith RL, Bazer FW and Sharp DC (1984) Effect of exogenous gonadal steroids and pregnancy on uterine luminal $\mathrm{PGF}_{2 u}$ in mares Prostaglandins 27 311-320 